\title{
RESEARCH
}

Open Access

\section{Introduction of Dalbergia odorifera enhances nitrogen absorption on Eucalyptus through stimulating microbially mediated soil nitrogen-cycling}

\author{
Xianyu Yao ${ }^{1,2,3}$, Qianchun Zhang ${ }^{3}$, Haiju Zhou ${ }^{3}$, Zhi Nong ${ }^{4}$, Shaoming Ye (3* $^{3^{*}}$ and Qi Deng ${ }^{1,2^{*}}$ [D
}

\begin{abstract}
Background: There is substantial evidence that Eucalyptus for nitrogen $(\mathrm{N})$ absorption and increasing the growth benefit from the introduction of $\mathrm{N}$-fixing species, but the underlying mechanisms for microbially mediated soil $\mathrm{N}$ cycling remains unclear.

Methods: We investigated the changes of soil pH, soil water content (SWC), soil organic carbon (SOC), total N (TN), inorganic $\mathrm{N}\left(\mathrm{NH}_{4}{ }^{+}-\mathrm{N}\right.$ and $\left.\mathrm{NO}_{3}{ }^{-}-\mathrm{N}\right)$, microbial biomass and three $\mathrm{N}$-degrading enzyme activities as well as the biomass and $\mathrm{N}$ productivity of Eucalyptus between a pure Eucalyptus urophylla $\times$ grandis plantation (PP) and a mixed Dalbergia odorifera and Eucalyptus plantation (MP) in Guangxi Zhuang Autonomous Region, China.

Results: Compared with the PP site, soil pH, SWC, SOC and TN in both seasons were significantly higher at the MP site, which in turn enhanced microbial biomass and the activities of soil N-degrading enzymes. The stimulated microbial activity at the MP site likely accelerate soil $\mathrm{N}$ mineralization, providing more available $\mathrm{N}\left(\mathrm{NH}_{4}{ }^{+}-\mathrm{N}\right.$ in both seasons and $\mathrm{NO}_{3}{ }^{-}-\mathrm{N}$ in the wet-hot season) for Eucalyptus absorption. Overall, the $\mathrm{N}$ productivity of Eucalyptus at the MP site was increased by $19.7 \%$ and $21.9 \%$, promoting the biomass increases of $15.1 \%$ and $19.2 \%$ in the drycold season and wet-hot season, respectively.

Conclusion: Our results reveal the importance of microbially mediated soil $\mathrm{N}$ cycling in the $\mathrm{N}$ absorption on Eucalyptus. Introduction of D. odorifera enhances Eucalyptus biomass and N productivity, improve soil N availability and increased soil $\mathrm{C}$ and $\mathrm{N}$ concentration, which hence can be considered to be an effective sustainable management option of Eucalyptus plantations.
\end{abstract}

Keywords: Eucalyptus plantations, Soil physical-chemical properties, Microbial biomass, Soil enzyme activities, Nitrogen availability

\footnotetext{
*Correspondence: yshaoming@163.com; dengqi@scbg.ac.cn

${ }^{3}$ State Key Laboratory of Conservation and Utilization of Subtropical

Agro-bioresources, College of Forestry, Guangxi University, Nanning 530004

China

'Key Laboratory of Vegetation Restoration and Management of Degraded Ecosystems, South China Botanical Garden, Chinese Academy of Sciences,

Guangzhou 510650, China

Full list of author information is available at the end of the article
}

\section{Springer Open}

๑) The Author(s). 2021 Open Access This article is licensed under a Creative Commons Attribution 4.0 International License, which permits use, sharing, adaptation, distribution and reproduction in any medium or format, as long as you give appropriate credit to the original author(s) and the source, provide a link to the Creative Commons licence, and indicate if changes were made. The images or other third party material in this article are included in the article's Creative Commons licence, unless indicated otherwise in a credit line to the material. If material is not included in the article's Creative Commons licence and your intended use is not permitted by statutory regulation or exceeds the permitted use, you will need to obtain permission directly from the copyright holder. To view a copy of this licence, visit http://creativecommons.org/licenses/by/4.0/. 


\section{Background}

Eucalyptus is one of the most extensively planted commercial plantation timber genera in the world (Lino et al. 2016), and it has been introduced and cultivated in China since the 1970s. The area of Eucalyptus plantations in China has reached 4.6 million ha by 2014, of which almost half in Guangxi Zhuang Autonomous Region, China (Zhao et al. 2018). Currently, most Eucalyptus plantations are grown as monocultures and have been intensively managed in short-rotation with continuous cropping (Huang et al. 2017). However, due to high nitrogen $(\mathrm{N})$ consumption with successive rotations, the monoculture plantations of Eucalyptus have rapidly depleted soil nutrients (especially N) and water (Liu et al. 1998; Sicardi et al. 2004). The massive application of $\mathrm{N}$ fertilizer is common to ensure high and sustainable stand production (Laclau et al. 2005), but this not only increases economic costs but also leads to soil acidification and contamination of groundwater, and other negative impacts on the environment (Goncalves et al. 1997). Consequently, seeking an optimal silvicultural practice to achieve $\mathrm{N}$ sustainable management of Eucalyptus plantations is in urgent need.

The $\mathrm{N}$-fixing trees have been widely considered as being important in balancing $\mathrm{N}$ losses due to timber harvesting and in reducing the demand for fertilizer application in Eucalyptus plantations (May and Attiwill 2003). The growth of $\mathrm{N}$-fixing plants relies largely on the fixed atmospheric- $\mathrm{N}$ that accounts for $10 \%-90 \%$ of the $\mathrm{N}$ used by the $\mathrm{N}$-fixing species (Nygren and Leblanc 2015). Therefore, introduction of $\mathrm{N}$-fixing species into Eucalyptus plantations would decrease the $\mathrm{N}$ uptake of trees from soil, in turn increasing soil $\mathrm{N}$ retention (Bouillet et al. 2008; Koutika et al. 2019). In addition, the $\mathrm{N}$ transfer probably can also occur via mycorrhizal associations from acacia to eucalypt (Paula et al. 2015; Oliveira et al. 2021), which allows Eucalyptus to benefit directly from symbiotic $\mathrm{N}$ fixation (Paula et al. 2015; Yao et al. 2019, 2021). In recent years, introducing $\mathrm{N}$-fixing species to improve $\mathrm{N}$ absorption and biomass productivity on Eucalyptus has been a popular focus of research, but the experimental results remain contradictory depending on the selected $\mathrm{N}$-fixing species and stand conditions (Forrester et al. 2006; Firn et al. 2007; Bouillet et al. 2013). Moreover, because of lack of understanding the underlying mechanisms of soil $\mathrm{N}$ cycling, it is still hard to predict how combinations of the N-fixing species and specific sites can lead to the best benefits, making the extension of this silvicultural practice remains difficult around the world (Forrester et al. 2006).

The advantages of Eucalyptus mixed with $\mathrm{N}_{2}$-fixing tree species are usually attributed to the increase in soil organic N source (Paula et al. 2015; Yao et al. 2019). However, it is important to note that most of these increased organic $\mathrm{N}$ sources due to the introduction of $\mathrm{N}$-fixing species becoming available to Eucalyptus have to be transformed to inorganic $\mathrm{N}$ by the microbial decomposition of the plant tissues and soil organic matter (Versini et al. 2016). Shift of microbial activity under the mixed plantation of Eucalyptus and $\mathrm{N}$-fixing species would alter soil $\mathrm{N}$ cycling and availability, which ultimately improve the $\mathrm{N}$ absorption and growth on Eucalyptus (Huang et al. 2014). Microorganisms involve soil biogeochemical cycling mainly through producing specific extracellular enzymes, which has been confirmed by extensive researches (Huang et al. 2017). Soil Ndegrading enzymes including leucine aminopeptidase (LAP), $\beta-1,4-\mathrm{N}$-acetylglucosaminidase (NAG) and urease can serve as indicators of energy $\mathrm{N}$ demand (Schimel et al. 2017), which catalyze terminal reactions to depolymerize organic N (Sinsabaugh et al. 2008). Therefore, detecting the change of microbial biomass and soil $\mathrm{N}$-degrading enzyme activities will help us to better understand the underlying mechanisms for microbially mediated soil $\mathrm{N}$ cycling under the mixed plantations of Eucalyptus and $\mathrm{N}$-fixing species.

In recent years, a variety of $\mathrm{N}$-fixing species such as Acacia mangium and D. odorifera were introduced to improve $\mathrm{N}$ absorption and productivity on Eucalyptus planations in Guangxi (Yao et al. 2019). Previous work in pot experiment has observed a percentage of $6.6 \%-$ $13.6 \% \mathrm{~N}$ transfer from $D$. odorifera to Eucalyptus and an increase of $20.4 \%-33.2 \%$ in the dry matter yields of $E u$ calyptus compared to the monoculture plantation (Yao et al. 2019). The aim of this study is to better understand the underlying mechanisms for microbially mediated soil $\mathrm{N}$ cycling when introducing D. odorifera into the Eucalyptus plantations. Specifically, we hypothesized that the introduction of $D$. odorifera would increase soil organic matter (SOC and TN) and improve soil pH and SWC, which in turn stimulated microbial activities (biomass and $\mathrm{N}$-degrading enzyme activities) and increased $\mathrm{N}$ availability $\left(\mathrm{NH}_{4}{ }^{+}-\mathrm{N}\right.$ and $\left.\mathrm{NO}_{3}{ }^{-}-\mathrm{N}\right)$, ultimately enhancing Eucalyptus $\mathrm{N}$ absorption and productivity. We also expected that the role and the driving factors of microbially mediated soil $\mathrm{N}$ cycling when introducing $D$. odorifera into the Eucalyptus plantations differ between in the dry-cold and wet-hot seasons.

\section{Materials and methods}

\section{Experimental design}

The study site was located at the Experimental Center of Tropical Forestry, Chinese Academy of Forestry $\left(22^{\circ} 07^{\prime}\right.$ N, $106^{\circ} 93^{\prime}$ E), Pingxiang City, Guangxi Zhuang Autonomous Region, China. The mean annual precipitation is around $1400 \mathrm{~mm}$, falling mainly from April through September (Wang et al. 2010) and mean annual temperature is $21^{\circ} \mathrm{C}$. The soils were formed from granite, classified 
as red soil in Chinese soil classification, equivalent to oxisol in USDA Soil Taxonomy (Huang et al. 2014, 2017). Prior to the current study, this area was covered by a planted Acacia mangium plantations, which was established in 2001 on a historically deforested hill and clear harvested in 2014.

In March 2015, a complete randomized block design with three replicates was established to compare a pure $E$. urophylla $\times$ grandis plantation $(\mathrm{PP})$ and a mixed species plantation of $D$. odorifera and E. urophylla $\times$ grandis (MP) in a field experiment. The two species were planted alternately at 2-m spacing in the row, with $2.5 \mathrm{~m}$ between rows, giving a total stocking density of 2000 trees $\cdot \mathrm{ha}^{-1}$. These densities reflect the current densities in commercial plantations in South China. Each plot consisted in $15 \mathrm{~m} \times 15 \mathrm{~m}$ and a 200-m buffer separates the PP and MP plantations, and were either pure plots of E. urophylla $\times$ grandis $(100 \mathrm{E})$ or mixed plots in a proportion of 1:1 of both species (50D:50E, the two species being alternately planted in the row, and between adjacent rows). The fertilizers applied on planting were 140 g N.plant ${ }^{-1}$ (urea: $\mathrm{CO}\left({ }^{14} \mathrm{NH}_{2}\right)_{2}$, buried at $20 \mathrm{~cm}$ from the each plant), as well as $18 \mathrm{~g}^{\text {pplant }}{ }^{-1} \mathrm{~K}(\mathrm{KCl}), 56 \mathrm{~g}$ P.plant ${ }^{-1}\left(\mathrm{CaH}_{2} \mathrm{PO}_{4}\right)$ in both PP and MP plantations.

\section{Sample of plants collected and $\mathrm{N}$ analysis}

Five plants in each plot were harvested on March 20 and August 25, 2019, which including below-ground (i.e., roots) and above-ground. The trees of above-ground were separated into components: leaves, branches (living branches and dead branches), stem wood and stem bark. The stem of each tree was sawn into 2-m sections according to Monsic's stratified clip method (You et al. 2018). However, much of the root growth was shallow and lateral, it was difficult to distinguish the fine roots of one tree from those of another. To address this problem, a large soil pit of $1.5-\mathrm{m}$ diameter and $1.0-\mathrm{m}$ depth was excavated around each target tree. All the materials were collected and weighed up fresh weight immediately, and then $500 \mathrm{~g}$ of every composition sample was taken in laboratory.

The harvested material was dried at $65^{\circ} \mathrm{C}$ until constant dry weight period for the biomass analyses. The dried plant material was ground in a ball mill $(<0.1 \mathrm{~mm})$ for the $\mathrm{N}$ concentration analyses with a continuous-flow chemical analyzer (AA3) after the degradation using 10 $\mathrm{mL} \mathrm{H}_{2} \mathrm{SO}_{4}$. The biomass and $\mathrm{N}$ accumulation of $E$. urophylla $\times$ grandis in the pot was the sum of leaves, stem, branches, bark and roots.

\section{Sample of soils collected and analysis}

On March 19 and August 24, representing the dry-cool season and the wet-hot seasons of the year 2019, respectively, five soil samples were randomly collected from each plot at $0-20 \mathrm{~cm}$ depth to investigated the changes of soil $\mathrm{pH}$, soil water content (SWC), soil organic carbon (SOC), total $\mathrm{N}(\mathrm{TN})$, inorganic $\mathrm{N}$ (ammonium nitrogen: $\mathrm{NH}_{4}{ }^{+}-\mathrm{N}$ and nitrate nitrogen: $\left.\mathrm{NO}_{3}{ }^{-}-\mathrm{N}\right)$, microbial biomass and three $\mathrm{N}$-degrading enzyme activities. During sampling within a plot, the corer was wiped clean of obvious soil particles with paper towel. All samples were stored at $-20^{\circ} \mathrm{C}$ and sieved $<2 \mathrm{~mm}$ to remove visible stones, soil animals, roots and plant materials prior to analysis $\mathrm{pH}$, ammonium $\left(\mathrm{NH}_{4}{ }^{+}-\mathrm{N}\right)$ and nitrate nitrogen $\left(\mathrm{NO}_{3}{ }^{-}-\mathrm{N}\right)$. Some of the air dried and ball milled sample (sieved $<0.2$ $\mathrm{mm}$ ) were used for the concentration of total nitrogen $\mathrm{TN}$, soil microbial biomass carbon (MBC) and nitrogen (MBN) and (SOC analyses.

The $\mathrm{pH}$ of the soil samples was measured in a 1:2.5 soil/water suspension. SOC was determined by dichromate oxidation and titration with ferrous ammonium sulfate, the TN concentration was determined by a continuous flow chemical analyzer (AA3) and followed by detection of $\mathrm{NH}_{4}{ }^{+}-\mathrm{N}$ and $\mathrm{NO}_{3}{ }^{-}-\mathrm{N}$. Data was also collected on $\mathrm{C} / \mathrm{N}$ ratio of soil ( $\mathrm{C} / \mathrm{Nsoil})$.

$\mathrm{MBC}$ and $\mathrm{MBN}$ were measured by fumigationextraction, using $0.5 \mathrm{M} \mathrm{K}_{2} \mathrm{SO}_{4}$ as the extraction agent (Vance et al. 1987), with a total organic carbon analyzer (1020A; OI, College Station, TX, USA), and were calculated by Vance et al. (1987).

In addition, soil microbial function was expressed by the soil extracellular enzyme activities, involved NAG, LAP and Urease, respectively. We determined the soil enzyme activities using the conventional p-nitrophenol (pNP) assays (Baldrian 2009). The enzyme activities were measured by 3 replicates for each soil sample and expressed as $\mu \mathrm{mol}$ per gram dry soil and incubation time.

\section{Statistical analyses}

Statistical analyses were performed using SPSS software (SPSS Inc., Chicago, IL, USA). Analysis of Variance (ANOVA) was used to determine the statistical significance $(\alpha=0.05)$ of stand type, season and their interactive effect on $\mathrm{N}$ accumulation and biomass of Eucalyptus as well as soil physico-chemical properties and microbial activity. Tukey's multiple comparison test (HSD) was conducted if significant effects of stand type or season was found. Pairwise relationships between plant $\mathrm{N}$ accumulation, soil physico-chemical properties and microbial activities were tested using Pearson correlation coefficients.

Structural equation modeling (SEM) is an advanced multivariate statistical technique that allows for hypotheses testing of complex path-relation networks (Grace et al. 2007). A structural equation modelling (SEM) approach was also used to test a conceptual model for 
microbially mediated soil $\mathrm{N}$ cycling in the dry-cold and the wet-hot seasons. The SEM analysis was performed with the IBM SPSS Amos 20.0 using the maximum likelihood estimation method. Several tests were used to assess model fit: the Chi-square $\left(x^{2}\right)$-test, comparative fit index (CFI) and root square mean error of approximation (RMSEM) (Arbuckle 2006).

\section{Results}

\section{The biomass and $\mathrm{N}$ productivity of $E$. urophylla $\times$ grandis}

The total biomass of Eucalyptus was significantly affected by stand type (Table S1), with greater at the MP than the PP sites in both seasons (Fig. 1a and b; $p<$ 0.05). For the different organs of Eucalyptus, the biomass in branch and stem were significantly greater at the MP than PP sites in the wet-hot season, while in the drycold season only the leaf biomass were significantly greater at the MP than PP sites. At both PP and MP sites, the biomass of Eucalyptus in stems was greatest, and then followed by root, branch, bark and leaf in both seasons (Fig. 1a and b). The $\mathrm{N}$ productivity of the whole plant was significantly affected by season, stand type and their interaction (Table S1). Similar to biomass, the total $\mathrm{N}$ productivity of Eucalyptus was also significantly greater at the MP than the PP sites in the both seasons (Fig. 1c and d). For the different organs of Eucalyptus, the $\mathrm{N}$ productivity in leaf, branch and root were significantly greater at the MP than PP sites in the wet-hot season, while in the dry-cold season only the leaf $\mathrm{N}$ productivity were significantly greater at the MP than PP sites. More importantly, the increased N productivity of Eucalyptus with the introduction of D. odorifera was relatively greater in leaf than in the other organs (Fig. 1c and $\mathrm{d}$ ). The distribution of $\mathrm{N}$ productivity in different organs from high to low were stem, root, ranch, bark and leaf in the dry-cold season and were stem, branch, leaf, root and bark in the wet-hot season, respectively (Fig. 1c and d).

\section{Soil physico-chemical properties}

Soil $\mathrm{pH}$ had no significant difference between the drycold and wet-hot season, but was significantly higher at the MP site than at the PP site (Table 1). The concentrations of SOC, TN, $\mathrm{NO}_{3}{ }^{-}-\mathrm{N}$ and $\mathrm{NH}_{4}{ }^{+}-\mathrm{N}$ as well as the ratio of SOC to TN $(\mathrm{C} / \mathrm{N})$ and SWC were significantly affected by stand type and season. SOC, TN, $\mathrm{NH}_{4}{ }^{+}-\mathrm{N}$ and SWC were significantly higher at the MP than the PP sites and in the wet-hot season than dry-cold season
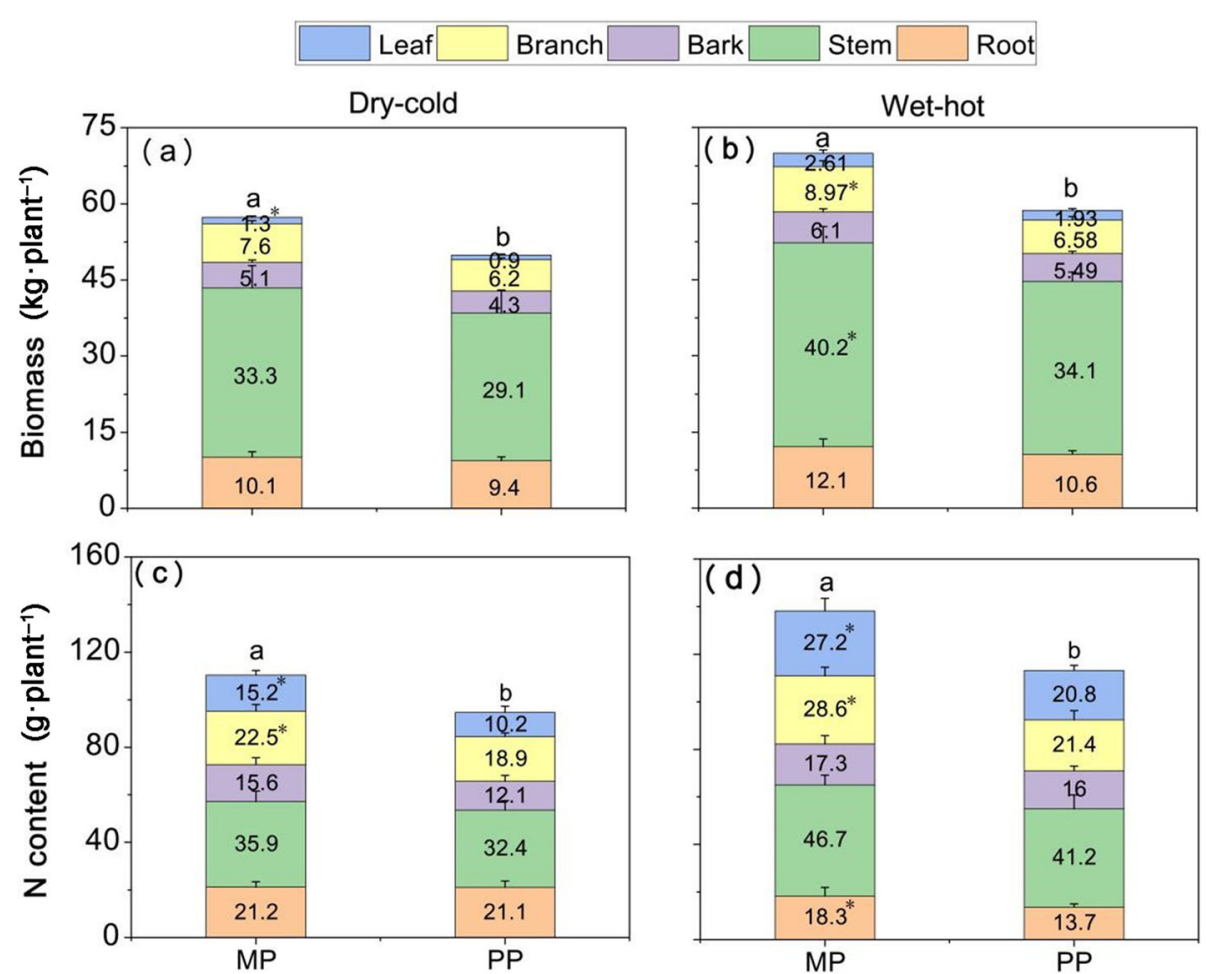

Fig. 1 The biomass and the $N$ accumulation of E. urophylla $\times$ grandis on pure Eucalyptus and mixed with $\mathrm{N}_{2}$-fixing species and Eucalyptus, respectively. $\mathbf{a}, \mathbf{b}$ represent the biomass of $E$. urophylla $\times$ grandis and $\mathbf{c}$, $\mathbf{d}$ represent the $\mathrm{N}$ content of $E$. urophylla $\times$ grandis in dry-cold season and wet-hot season, respectively. PP = pure Eucalyptus plantations; $\mathrm{MP}=$ mixed with $\mathrm{N}_{2}$-fixing species Eucalyptus plantations. Different lowercase letters ( $\mathbf{a}$ and $\mathbf{b}$ ) on the barks are different significantly of the whole plant $(p<0.05)$ and ${ }^{*}$ is different significantly in the same organ between the PP and MP site. Error bars indicate \pm SE $(n=4)$ 
Table 1 Soil Physical chemical properties as affected by introduction $\mathrm{N}_{2}$-fixing trees and seasons in Eucalyptus plantations. PP = pure Eucalyptus plantation; MP = mixed with $\mathrm{N}_{2}$-fixing species and Eucalyptus plantation

\begin{tabular}{|c|c|c|c|c|c|c|c|c|}
\hline \multicolumn{2}{|c|}{ Source of variation } & \multirow{2}{*}{$\frac{\mathbf{p H}}{4.83 \pm 0.12 \mathrm{a}}$} & \multirow{2}{*}{$\frac{\text { SWC (\%) }}{18.63 \pm 1.43 b}$} & \multirow{2}{*}{$\frac{\text { SOC }\left(\mathbf{g} \cdot \mathbf{k g}^{\mathbf{- 1}} \mathbf{)}\right.}{21.49 \pm 3.25 \mathrm{~b}}$} & \multirow{2}{*}{$\frac{\mathbf{T N}\left(\mathbf{g} \cdot \mathbf{k g}^{-\mathbf{1}}\right)}{1.34 \pm 0.13 \mathrm{~b}}$} & \multirow{2}{*}{$\frac{\left.\mathbf{N O}_{\mathbf{3}}{ }^{-} \mathbf{-} \mathbf{~ ( ~} \mathbf{m g} \cdot \mathbf{k g}^{-\mathbf{~}}\right)}{4.22 \pm 0.46 \mathrm{~b}}$} & \multirow{2}{*}{$\frac{\mathbf{N H}_{\mathbf{4}}{ }^{+} \mathbf{- N}\left(\mathbf{m g} \cdot \mathbf{k g}^{-\mathbf{1}}\right)}{16.99 \pm 3.17 \mathrm{~b}}$} & \multirow{2}{*}{$\frac{\mathrm{C} / \mathrm{N}}{16.09 \pm 2.03 \mathrm{~b}}$} \\
\hline Dry-cold & MP & & & & & & & \\
\hline & PP & $4.56 \pm 0.27 b$ & $16.83 \pm 0.86 c$ & $18.96 \pm 2.81 c$ & $1.04 \pm 0.15 c$ & $4.09 \pm 0.36 b$ & $13.55 \pm 2.01 c$ & $18.78 \pm 3.14 \mathrm{a}$ \\
\hline \multirow[t]{2}{*}{ Wet-hot } & MP & $4.91 \pm 0.16 \mathrm{a}$ & $21.48 \pm 1.63 \mathrm{a}$ & $24.70 \pm 3.62 \mathrm{a}$ & $1.56 \pm 0.15 a$ & $5.94 \pm 0.88 \mathrm{a}$ & $17.46 \pm 1.48 \mathrm{a}$ & $16.29 \pm 3.69 b$ \\
\hline & PP & $4.60 \pm 0.14 b$ & $19.99 \pm 1.11 b$ & $20.85 \pm 2.57 b$ & $1.12 \pm 0.10 c$ & $4.25 \pm 0.27 b$ & $13.59 \pm 1.56 c$ & $18.15 \pm 0.94 a$ \\
\hline \multicolumn{2}{|c|}{ Season (S) } & ns & $64.832^{* * *}$ & $25.48^{* * *}$ & $100.852^{* * *}$ & $87.659^{* * *}$ & $144.709^{* * *}$ & ns \\
\hline \multicolumn{2}{|c|}{ Stand type (T) } & $7.844^{*}$ & $19.332^{* * *}$ & $18.631^{* * *}$ & $9.330^{* *}$ & $48.121^{* * *}$ & $24.905^{* * *}$ & $7.844^{*}$ \\
\hline \multicolumn{2}{|l|}{$S \times T$} & ns & $\mathrm{ns}$ & ns & $8.522^{* *}$ & $50.178^{* * *}$ & $13.667^{* * *}$ & ns \\
\hline
\end{tabular}

$\mathrm{ns}^{*},{ }^{* *}$ and ${ }^{* * *}=$ F-value not significant, significant at $p>0.05$ and $p<0.05, p<0.01$ and $p<0.001$, respectively

$\left(p<0.05\right.$ for all, Table 1). The soil $\mathrm{NO}_{3}{ }^{-} \mathrm{N}$ concentration at the MP site was higher than that at the PP site in the wet-hot season only (Table 1 ). Compared with the $\mathrm{PP}$ site, soil $\mathrm{C} / \mathrm{N}$ ratio was significantly decreased at the MP site in both seasons (Table 1).

\section{Microbial biomass and enzymes activities}

Two-way ANOVAs showed that MBC and MBN were significantly affected by stand type and season $(p<0.05$, Fig. 2), but no significant interactive effect was found $(p>0.05$, Fig. 2). The MBC and MBN were significantly higher at the MP than the PP sites and in the wet-hot season than dry-cold season (Fig. 2a and b). However, the ratio of $\mathrm{MBC} / \mathrm{MBN}$ did not significantly differ between the PP and MP sites in the both seasons (Fig. 2c). All of the soil $\mathrm{N}$-degrading enzyme activities were also significantly affected by stand type and season $(p<0.05$, Fig. 3). Specifically, only the activities of NAG and Urea in the wet-hot season were significantly higher $(p<0.05)$ at the MP than the PP sites (Fig. 3).

\section{Relationships of soil microbial biomass and enzymes activities with soil and plant $\mathbf{N}$ pools}

Soil pH did not correlated with any other properties in the dry-cold season, while in the wet-hot season it was positively correlated with SWC, SOC, TN, NAG activity and $\mathrm{NO}_{3}{ }^{-} \mathrm{N}$ (Table 2). SWC was positively correlated with MBC, the activities of NAG and Urea, and the N accumulation of Eucalyptus in the dry-cold season, and with SOC, TN, NAG activity, $\mathrm{NH}_{4}{ }^{+}-\mathrm{N}, \mathrm{NO}_{3}{ }^{-}-\mathrm{N}$ and the $\mathrm{N}$ accumulation of Eucalyptus in the wet-hot season, respectively (Table 2). SOC also did not correlated with any other properties in the dry-cold season, but in the wet-hot season it was positively correlated with $\mathrm{TN}$, $\mathrm{MBC}$, all of $\mathrm{N}$-degrading enzyme activities, $\mathrm{NH}_{4}{ }^{+}-\mathrm{N}$, $\mathrm{NO}_{3}{ }^{-}-\mathrm{N}$ and the $\mathrm{N}$ accumulation of Eucalyptus in the wet-hot season. Soil TN content was positively correlated with MBN and the $\mathrm{N}$ accumulation of Eucalyptus in the dry-cool season, and with MBC, the activities of NAG and Urea, $\mathrm{NO}_{3}{ }^{-}-\mathrm{N}$ and the $\mathrm{N}$ accumulation of $\mathrm{Eu}-$ calyptus in the wet-hot season, respectively (Table 2 ).
MBC and MBN were positively correlated with all of the $\mathrm{N}$-degrading enzyme activities in the wet-hot season expect for the relationship between MBN and LAP activity (Table 2). MBC was also positively correlated with $\mathrm{NH}_{4}{ }^{+}-\mathrm{N}, \mathrm{NO}_{3}{ }^{-}-\mathrm{N}$ and the $\mathrm{N}$ accumulation of Eucalyptus in the wet-hot season (Table 2). NAG activity was positively correlated with $\mathrm{NH}_{4}{ }^{+}-\mathrm{N}, \mathrm{NO}_{3}{ }^{-}-\mathrm{N}$ and the $\mathrm{N}$ accumulation of Eucalyptus in both seasons (Table 2). LAP activity was positively correlated with $\mathrm{NH}_{4}{ }^{+}-\mathrm{N}$ and the $\mathrm{N}$ accumulation of Eucalyptus in the wet-hot season but not in the dry-cold season, while Urea activity was positively correlated with $\mathrm{NH}_{4}{ }^{+}-\mathrm{N}$ and the $\mathrm{N}$ accumulation of Eucalyptus in the dry-cold season but not in the wethot season (Table 2). Both $\mathrm{NH}_{4}{ }^{+}-\mathrm{N}$ and $\mathrm{NO}_{3}{ }^{-}-\mathrm{N}$ were positively correlated with the $\mathrm{N}$ accumulation of Eucalyptus in the wet-hot season, while in the dry-cold season only the $\mathrm{NH}_{4}{ }^{+}-\mathrm{N}$ was positively correlated with the $\mathrm{N}$ accumulation of Eucalyptus (Table 2).

\section{Pathway analysis for Eucalyptus to enhance $\mathrm{N}$ uptake}

The structural equation model on the regulatory pathway of soil $\mathrm{N}$ dynamics well passed all the statistical tests on adequacy of microbial biomass and enzyme activities (Fig. 4a and b). Overall, soil pH, SWC, SOC and TN in both seasons were significantly higher at the MP than PP sites (Table 1), which together stimulated microbial biomass and most of soil N-related enzyme activities although the control mechanisms are different between seasons (Fig. 4a and b). The enhanced microbial activity likely accelerated soil $\mathrm{N}$ mineralization, providing more available $\mathrm{N}\left(\mathrm{NH}_{4}{ }^{+}-\mathrm{N}\right.$ and $\left.\mathrm{NO}_{3}{ }^{-}-\mathrm{N}\right)$ for Eucalyptus absorption. Path analysis pointed to direct and positive controls of soil $\mathrm{N}$ availability $\left(\mathrm{NH}_{4}{ }^{+}-\mathrm{N}\right.$ and $\left.\mathrm{NO}_{3}{ }^{-}-\mathrm{N}\right)$ by the activity of soil N-related enzymes in both seasons, but the significant control by microbial biomass on the soil $\mathrm{N}$ availability was observed in the wet-hot season only. Soil pH and SWC positively correlated with microbial biomass in the dry-cold season only. SOC and TN positively corrected with both microbial biomass and enzyme activity in the dry-cold season and there was also a positive relationship between microbial biomass and 

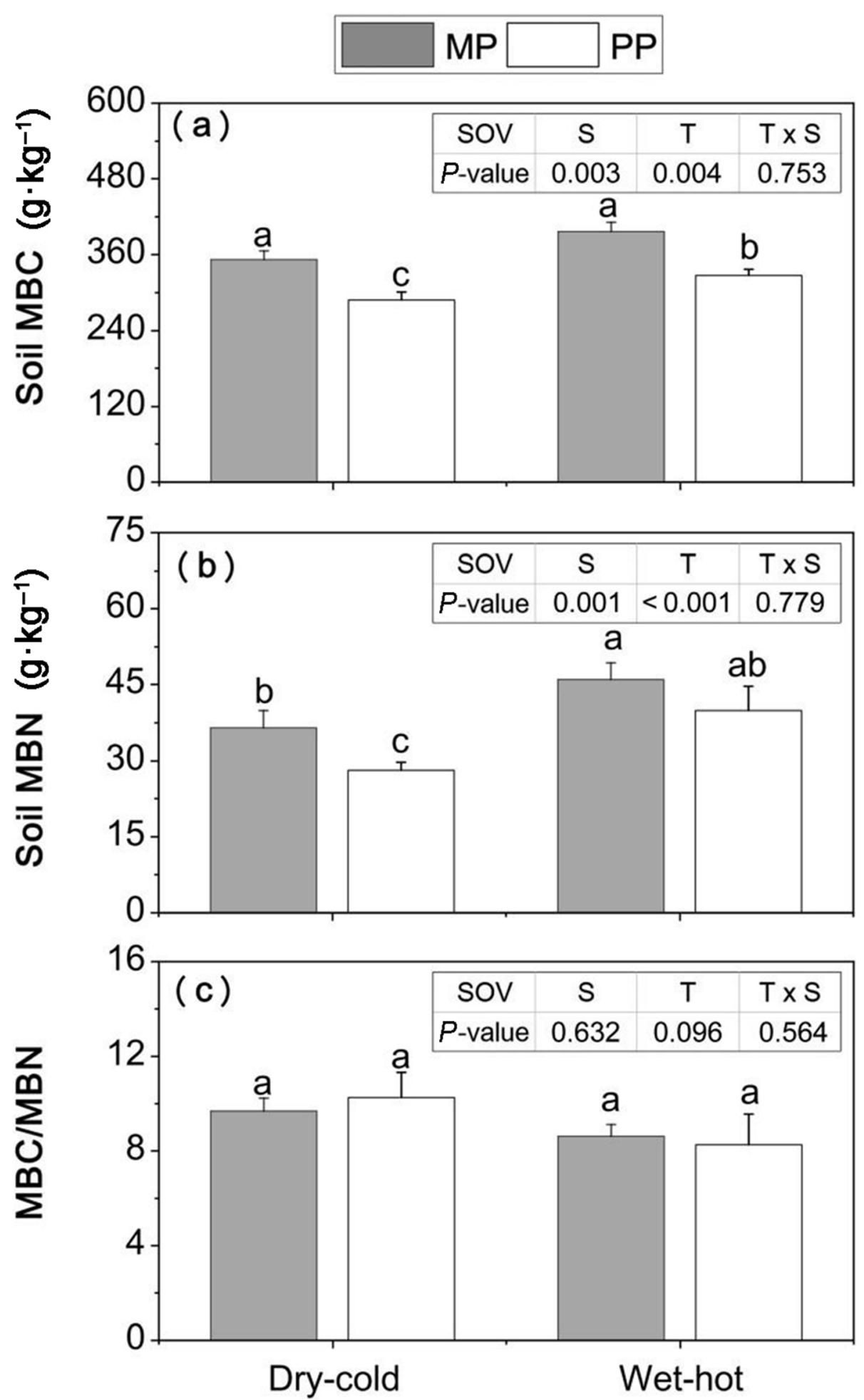

Fig. 2 The soil microbial biomass carbon $(\mathrm{MBC})(\mathbf{a})$, microbial biomass nitrogen $(\mathrm{MBN})(\mathbf{b})$ and $\mathrm{MBC}: \mathrm{MBN}$ ratio $(\mathbf{c})$ in the pure Eucalyptus plantations and mixed with $\mathrm{N}_{2}$-fixing species and Eucalyptus plantations in both dry-cold and wet-hot seasons. PP = pure Eucalyptus plantations; $\mathrm{MP}=$ mixed with $\mathrm{N}_{2}$-fixing species Eucalyptus plantations. Different lowercase letters $(\mathbf{a}, \mathbf{b}$ and $\mathbf{c}$ ) on the barks indicate significant differences under different treatments at $p<0.05$. Error bars indicate $\pm \mathrm{SE}(n=3)$. For the table in the top right-hand corner of figure, 'SOV', 'S', 'T' and 'S $\times T^{\prime}$ ' indicate that 'Source of variation', 'season' 'stand type' and 'interaction season $\times$ stand type', $P$-values show that was not significant and significant affected for $p>0.05$ and $p<0.05$ 

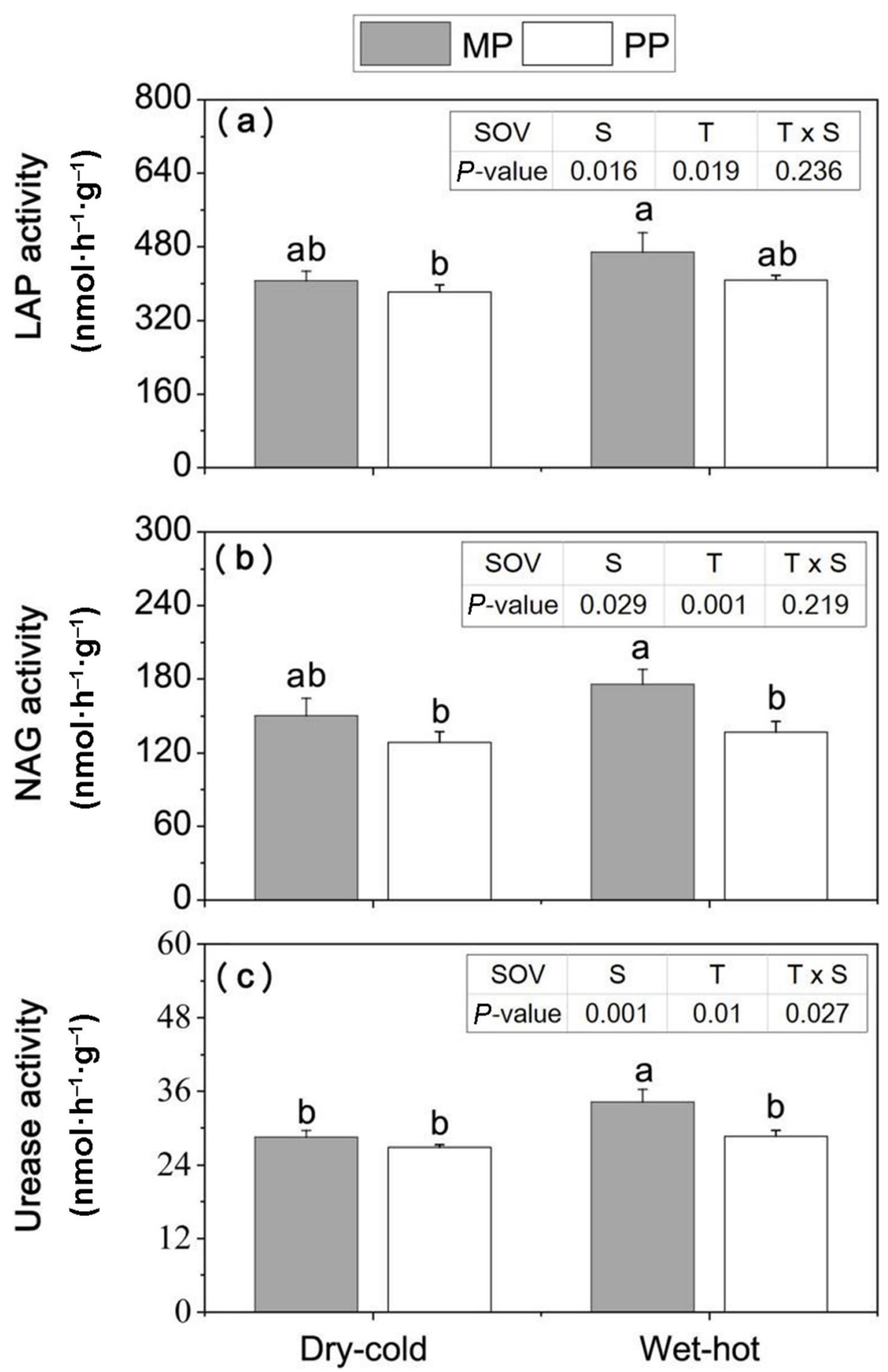

Fig. 3 The soil enzyme activities per gram of soil in the pure Eucalyptus plantations and mixed with $\mathrm{N}_{2}$-fixing species and Eucalyptus plantations in both dry-cold and wet-hot seasons. PP = pure Eucalyptus plantations; MP = mixed with $\mathrm{N}_{2}$-fixing species Eucalyptus plantations. Different lowercase letters ( $\mathrm{a}$ and $\mathrm{b}$ ) on the barks indicate significant differences under different treatments at $p<0.05$. Error bars indicate $\pm \mathrm{SE}(n=3)$. For the table in the top right-hand corner of figure, 'SOV', 'S', 'T' and 'S $\times \mathrm{T}^{\prime}$ indicate that 'Source of variation', 'season' 'stand type' and 'interaction season $\times$ stand type', $P$-values show that was not significant and significant affected for $p>0.05$ and $p<0.05$

enzyme activity in both seasons. SOC and TN did not directly affect soil enzyme activity, but have an indirect effect via influencing microbial biomass.

\section{Discussion}

Mixed plantations of Eucalyptus and N-fixing species have been recognized as one of effective silvicultural 
Table 2 The collection among the soil physical-chemical properties, soil enzymes, soil microbial biomass and $\mathrm{N}$ content in the plants

\begin{tabular}{|c|c|c|c|c|c|c|c|c|c|c|c|c|}
\hline $\begin{array}{l}\text { Source of } \\
\text { variation }\end{array}$ & $\mathrm{pH}$ & SWC & SOC & TN & MBC & MBN & LAP & NAG & Urease & $\mathrm{NH}_{4}{ }^{+}-\mathrm{N}$ & $\mathrm{NO}_{3}{ }^{-}-\mathrm{N}$ & PN \\
\hline$\overline{\mathrm{pH}}$ & & ns & ns & ns & ns & ns & ns & ns & ns & ns & ns & ns \\
\hline SWC & $0.976^{* *}$ & & $\mathrm{~ns}$ & $\mathrm{~ns}$ & $0.813^{\circ}$ & $\mathrm{ns}$ & $\mathrm{ns}$ & $0.895^{\circ}$ & $0.899^{\circ}$ & $\mathrm{ns}$ & $\mathrm{ns}$ & $0.946^{* *}$ \\
\hline SOC & $0.824^{*}$ & $0.857^{*}$ & & ns & $\mathrm{ns}$ & ns & $\mathrm{ns}$ & $\mathrm{ns}$ & $\mathrm{ns}$ & $\mathrm{ns}$ & $\mathrm{ns}$ & ns \\
\hline $\mathrm{TN}$ & $0.836^{\circ}$ & $0.87^{\circ}$ & $0.835^{\circ}$ & & ns & $0.864^{\circ}$ & ns & ns & ns & ns & ns & $0.818^{\circ}$ \\
\hline $\mathrm{MBC}$ & $\mathrm{ns}$ & $\mathrm{ns}$ & $0.888^{\circ}$ & $0.968^{* *}$ & & $\mathrm{~ns}$ & $\mathrm{~ns}$ & $\mathrm{~ns}$ & $\mathrm{~ns}$ & $\mathrm{~ns}$ & $\mathrm{~ns}$ & ns \\
\hline MBN & ns & ns & $\mathrm{ns}$ & ns & ns & & ns & ns & ns & ns & ns & ns \\
\hline LAP & $\mathrm{ns}$ & $\mathrm{ns}$ & $0.866^{\circ}$ & ns & $0.812^{*}$ & ns & & $\mathrm{ns}$ & ns & ns & ns & ns \\
\hline NAG & $0.889^{\circ}$ & $0.947^{* *}$ & $0.931^{* *}$ & $0.908^{\circ}$ & $0.978^{* *}$ & $0.825^{\circ}$ & $0.908^{*}$ & & $0.994^{* *}$ & $0.96^{\prime *}$ & $0.858^{\circ}$ & $0.962^{n *}$ \\
\hline Urease & ns & ns & $0.850^{\circ}$ & $0.855^{\circ}$ & $0.866^{\circ}$ & $0.859^{\circ}$ & $\mathrm{ns}$ & $0.861^{* *}$ & & $0.935^{* *}$ & $\mathrm{~ns}$ & $0.967^{*+}$ \\
\hline $\mathrm{NH}_{4}{ }^{+}-\mathrm{N}$ & $\mathrm{ns}$ & $0.859^{*}$ & $0.883^{*}$ & $\mathrm{~ns}$ & $0.894^{*}$ & $\mathrm{~ns}$ & $0.94^{* *}$ & $0.946^{* *}$ & ns & & $0.897^{*}$ & $0.877^{*}$ \\
\hline $\mathrm{NO}_{3}{ }^{-}-\mathrm{N}$ & $0.902^{\circ}$ & $0.910^{*}$ & $0.947^{* *}$ & $0.951^{* *}$ & $0.952^{* *}$ & $\mathrm{~ns}$ & $\mathrm{~ns}$ & $0.928^{\circ}$ & $\mathrm{ns}$ & $0.831^{\circ}$ & & ns \\
\hline PN & ns & $0.883^{\circ}$ & $0.873^{\circ}$ & $0.909^{* *}$ & $0.976^{* *}$ & $\mathrm{~ns}$ & $0.894^{\circ}$ & $0.984^{* *}$ & ns & $0.960^{* *}$ & $0.893^{\circ}$ & \\
\hline
\end{tabular}

SOC Soil organic carbon, $\mathrm{TN}$ Soil total nitrogen, $\mathrm{NH}_{4}{ }^{+}-\mathrm{N}$ Ammonium nitrogen, $\mathrm{NO}_{3}{ }^{-} \mathrm{N}$ Nitrate nitrogen, $\mathrm{PN}$ Plant nitrogen content, $\mathrm{MBC}$ Microbial biomass carbon $M B N$ Microbial biomass nitrogen, LAP Leucine aminopeptidase, NAG $\beta-1,4-\mathrm{N}$-acetylglucosaminidase. The values in the yellow area are in the wet-hot season and in the blue areas are in the dry-cool season. $\mathrm{ns}^{*}{ }^{*}$ and ${ }^{* *}=F$-value not significant, significant at $p>0.05$ and $p<0.05$ and $p<0.01$, respectively

practices to increase Eucalyptus productivity while maintaining soil fertility, compared to Eucalyptus monocultures (Epron et al. 2013; Tchichelle et al. 2017). For example, introducing Acacia mangium into E. grandis plantations provides better conditions for restoring the soil fertility and soil biodiversity, hence providing better sustainability of the cropping systems than pure $E$. grandis plantations (Garay et al. 2004). However, the results reported previously remain contradictory depending on the selected $\mathrm{N}$-fixing species and stand conditions (Forrester et al. 2006; Firn et al. 2007; Bouillet et al. 2013). In this study, we discovered that the biomass and N productivity of Eucalyptus as well as soil $\mathrm{TN}$ and $\mathrm{N}$ availability were significantly enhanced by introducing $D$. odorifera into the Eucalyptus plantations. More importantly, the increased $\mathrm{N}$ accumulation of $\mathrm{Eu}$ calyptus with the introduction of $D$. odorifera was relatively greater in leaf than in the other organs (Fig. 1c and d). This may suggest that introduction of $D$. odorifera enhanced $\mathrm{N}$ uptake of Eucalyptus, and the $\mathrm{N}$ was primarily distributed to leaves so that better stimulate leaf photosynthesis and Eucalyptus growth.

The enhanced $\mathrm{N}$ productivity on Eucalyptus with introduction of $D$. odorifera should be attributed to the improved soil $\mathrm{N}$ availability, as $\mathrm{N}$ productivity of Eucalyptus was directly correlated with both soil $\mathrm{NH}_{4}{ }^{+}-\mathrm{N}$ and $\mathrm{NO}_{3}{ }^{-} \mathrm{N}$ concentrations (Table 2). In agreement with our hypothesis, using structural equation model, we found that the higher soil organic matter (SOC and TN) and improved soil $\mathrm{pH}$ and SWC at the MP sites could indirectly enhance soil $\mathrm{N}$ availability via stimulating microbial activity (microbial biomass and enzyme activity). Increased soil TN under the mixed plantation of Eucalyptus and $\mathrm{N}_{2}$-fixing species is common, as the growth of $\mathrm{N}$-fixing plants relies largely on the fixed atmospheric-N (Paula et al. 2018). Therefore, introduction of $\mathrm{N}$-fixing species into Eucalyptus plantations would decrease the $\mathrm{N}$ uptake of trees from soil, in turn increasing soil $\mathrm{N}$ retention (Bouillet et al. 2008). Faster growth of $\mathrm{N}$-fixing tree species and Eucalyptus due to higher $\mathrm{N}$ availability at the MP sites could also increase the input of plant residuals and hence enhance SOC and TN. Similar results were also found in other studies with a mixed plantation such as E. globulus and A. mearnsii in Australia (Forrester et al. 2005), Eucalyptus grandis and Acacia mangium in Brazil (Bini et al. 2013a, 2013b) and in Congo (Koutika et al. 2019, 2020), or Eucalyptus regnans and Acacia dealbata in southeastern Australia (Pfautsch et al. 2009). Soil organic matter has a huge specific surface area (mainly by humic substances) and a large number of negative charges (Gruba and Mulder 2015). Thus, increased SOC and TN at the MP sites may have a greater capacity in adsorbing cations, resulting in higher soil pH (Jiang et al. 2018). The increased SWC at the MP sites may be attributed to higher understory coverage of $D$. odorifera and the decreased water uptake by Eucalyptus. These findings suggest that the presence of leguminous trees in the system could improve stand conditions such as provide advantageous soil $\mathrm{pH}$ and SWC and more substrate availability (higher SOC and $\mathrm{TN}$ as well as decreased soil C:N) for microbial proliferation and the production of specific extracellular enzymes (Bowles et al. 2014). Therefore, soil microbial biomass and the activities of $\mathrm{N}$-degrading enzymes in this study were generally higher at the MP than PP sites (Fig. 2). It is well known that increased microbial Ndegrading enzyme activities reflect a higher rate of $\mathrm{N}$ mineralization and a higher level of $\mathrm{N}$ availability (Tabatabai et al. 2010). Although we have not determined the $\mathrm{N}$ mineral processes in this study, previous studies have frequently found that introducing $\mathrm{N}$-fixing trees into $\mathrm{Eu}$ calyptus plantations can stimulate microbial activity (Pereira et al. 2018, 2019) to increase the rate of $\mathrm{N}$ mineralization (Voigtlaender et al. 2012, 2019). 


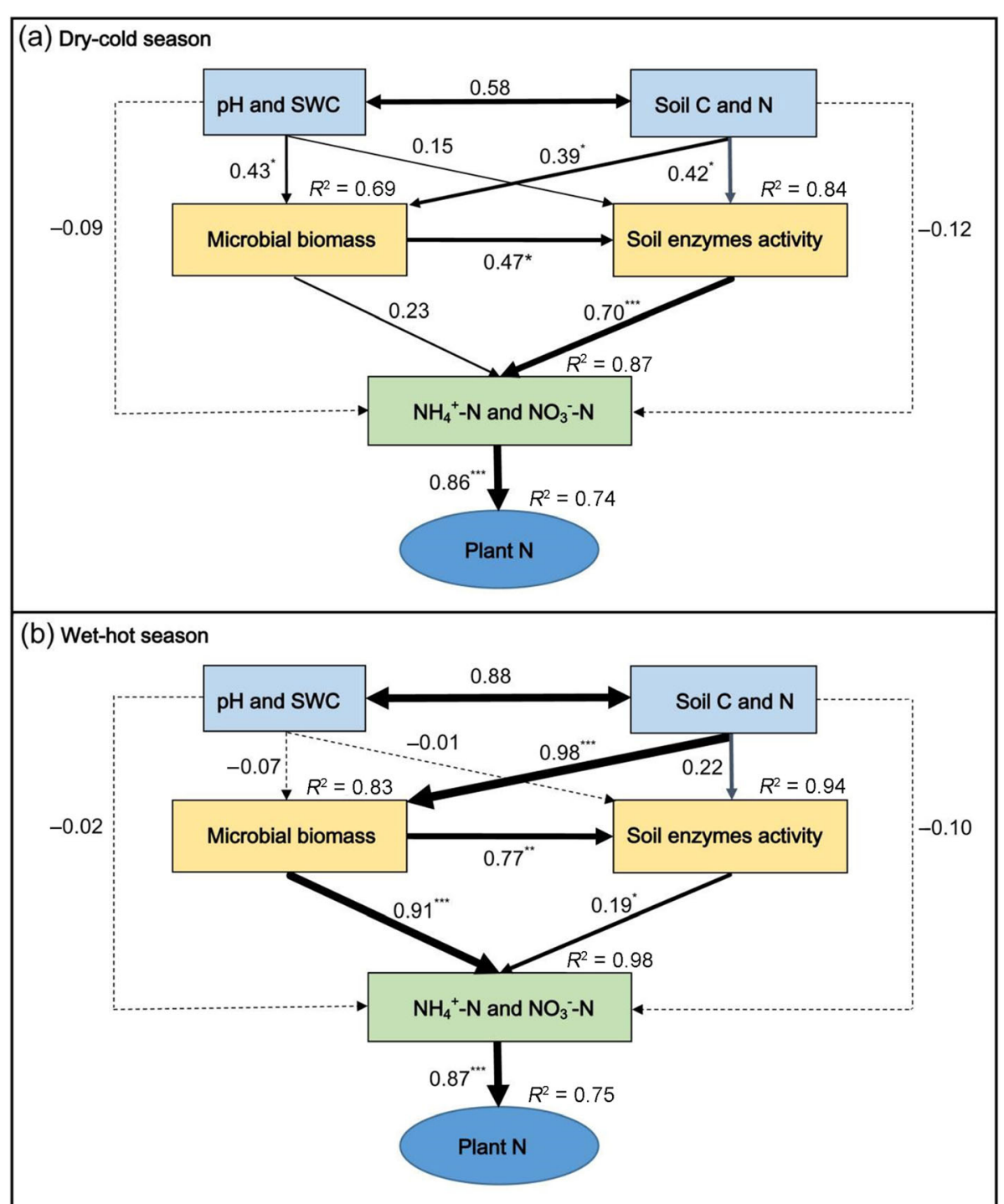

Fig. 4 Path model depicting the regulatory pathway of the controls of soil extracellular enzymes activities of soil physical-chemical properties (pH and soil water content: SWC), total nitrogen (TN), soil organic carbon (SOC) and microbial biomass (MBC and MBN) by the structural attributes to involve plant $\mathrm{N}$ absorption by plant. Where (a) represent structural equation model (SEM) in the dry-cold season for the model were $x^{2}=7.944$, $p=0.056, \mathrm{CMIN} / \mathrm{df}=1.986, \mathrm{GFI}=0.900, \mathrm{RMSEA}=0.050, \mathrm{CFI}=0.933$; and $(\mathbf{b})$ represent SEM in the wet-hot season for the model were $x^{2}=4.663$, $p=0.324, \mathrm{CMIN} / \mathrm{df}=1.166, \mathrm{GFI}=0.948, \mathrm{RMSEA}=0.026, \mathrm{CFI}=0.974$. The black solid lines and dotted lines indicate significant positive and negative relationships, respectively; the thickness of the arrows reflect the degree of relationships, numbers at arrows are standardized path coefficients, and $R^{2}$ values indicate the variation of response variables explained by the model. ${ }^{* * *}{ }^{*}$ and ${ }^{* * *}$ are different significantly at $p<0.05, p<0.01$ and $p<0.001$, respectively

As expected, we also found that the driving factors and the role of microbially mediated soil $\mathrm{N}$ cycling when introducing $D$. odorifera into the Eucalyptus plantations differed between the seasons in this study. In the drycold season, soil microorganisms are usually subject to water limitation. Thus, increased SWC under the MP site could stimulate microbial biomass and the activity of $\mathrm{N}$-degrading enzymes. This was supported by the positive relationship of SWC with MBC and the activities of NAG and Urease in the dry-cold season observed in this study (Table 2). The structural equation model pointed out that increased soil organic matter also has positive effects on microbial biomass and the activity of $\mathrm{N}$-degrading enzymes in the dry-cold season (Fig. 4a). However, we only found a positive relationship between $\mathrm{TN}$ and MBN in the dry-cold season (Table 2), suggesting that increased TN under the MP site might alleviate microbial $\mathrm{N}$ limitation and enhance microbial $\mathrm{N}$ assimilation. This in turn may explain why enhanced microbial biomass under the MP site did not directly contribute to 
higher $\mathrm{N}$ availability in the dry-cold season (Fig. 4a). In the wet-hot season, both temperature and SWC are relatively higher at our study sites, thus increased SWC and $\mathrm{pH}$ under the MP site did not significantly influence microbial biomass and the activity of N-degrading enzymes (Table 2 and Fig. 4b). Alternatively, we found direct and positive effects of SOC and TN on microbial biomass but indirect effect on the activity of N-degrading enzymes (Table 2 and Fig. 4b), suggesting that microbial biomass and the activity of $\mathrm{N}$-degrading enzymes in the wet-hot season was mainly limited by substrate availability in this study. Introduction of D. odorifera into Eucalyptus plantation significantly increased $\mathrm{MBC}$ but not MBN in the wet-hot season, thus having a direct and strong contribution to soil $\mathrm{N}$ availability (Fig. $4 \mathrm{~b}$ ). This was also supported by the positive relationships of $\mathrm{MBC}$ with $\mathrm{NH}_{4}{ }^{+}-\mathrm{N}$ or $\mathrm{NO}_{3}{ }^{-}-\mathrm{N}$ in the wet-hot season observed in this study (Table 2). Overall, introduction of D. odorifera into Eucalyptus plantation significantly increased soil $\mathrm{N}$ availability $\left(\mathrm{NH}_{4}{ }^{+}-\mathrm{N}\right.$ and $\left.\mathrm{NO}_{3}{ }^{-}-\mathrm{N}\right)$ with higher in the wet-hot season than dry-cold season, despite the plant demand for $\mathrm{N}$ is greater in the wet-hot season. This suggests that the increased soil organic matter (SOC and TN) driven microbially mediated soil $\mathrm{N}$ cycling may play a relative stronger role in $\mathrm{N}$ accumulation and biomass productivity of Eucalyptus at the MP site.

\section{Conclusion}

Compared with the Eucalyptus monoculture, we found that the biomass and $\mathrm{N}$ productivity of Eucalyptus were significantly increased by introducing $D$. odorifera into the Eucalyptus plantation. Introduction of $D$. odorifera into the Eucalyptus plantation could increase soil $\mathrm{pH}$, SWC, SOC and TN, which in turn enhanced microbial biomass and the activities of soil $\mathrm{N}$-degrading enzymes as well as soil $\mathrm{N}$ availability. With the structural equation models, our results reveal the importance of microbially mediated soil $\mathrm{N}$ cycling in the biomass and $\mathrm{N}$ productivity of Eucalyptus, while highlight the seasonal difference in the driving factors. Soil microbial biomass and the activities of soil $\mathrm{N}$-degrading enzymes in the dry-cold season were driven by increased SWC and TN, while in the wet-hot season they were mainly driven by increased SOC and TN. The mixed plantation also increased more soil $\mathrm{N}$ availability in the wet-hot season than dry-cold season. These findings can provide government and policy makers with useful tools to achieve $\mathrm{N}$ sustainable management in Eucalyptus plantations. However, further studies on the inclusion of litter quality and decomposition, soil next-generation sequencing as well as a longer time of evaluation are also essential to better understand the microbially mediated soil $\mathrm{N}$ cycling under the plantations of Eucalyptus and $\mathrm{N}$-fixing species.

\section{Abbreviations}

TN: Total nitrogen; SOC: Soil organic carbon; SWC: Soil water content; PP: Pure E. urophylla $\times$ grandis plantation; MP: A mixed species plantation of $D$. odorifera and E. urophylla $\times$ grandis; MBC: Soil microbial biomass carbon; MBN: Soil microbial biomass nitrogen; LAP: Leucine aminopeptidase; NAG: $\beta$ 1,4-N-acetylglucosaminidase

\section{Supplementary Information}

The online version contains supplementary material available at https://doi. org/10.1186/s40663-021-00339-3.

Additional file 1: Table S1 The $P$ values for season (S), stand type (T) and their interaction ANOVA effects on biomass and $\mathrm{N}$ content of Eucalyputs urophylla $\times$ grandis.

\section{Acknowledgements}

All who contributed towards the article who does not meet the criteria for authorship including anyone who provided professional writing services or materials have acknowledged.

The authors are grateful to Junfei Xiong at Chinese Academy of Forestry, Guangxi, China, for collecting the soils, harvesting and measuring of the plants in the field. We are also grateful to Dafeng Hui at Tennessee State University, Nashville, TN, USA, for his valuable comments and English improvements.

\section{Authors' contributions}

All the authors designed the experiments; Yao X, Nong Z and Zhang Q carried out the experiments; Yao $X, Y e S$ and Deng $Q$ analyzed the experimental results, Yao $\mathrm{X}$ and Zhou $\mathrm{H}$ analyzed the data and developed analysis tools; Yao X, Ye S and Deng Q wrote the manuscript, and all authors read and approved the final manuscript.

\section{Authors' information}

$X Y$ is a post-doctoral at South China Botanical Garden in Guangzhou, China. Doctor's Degree in Ecology at Guangxi University. He works on N transfer and cycling in mixed plantations Eucalyptus and N-fixing species. QZ is a master at Guangxi University in Guangxi, China. HZ is a master at Guangxi University in Guangxi, China. ZN is a technician at Chinese Academy of Forestry, China.

SY is a Professor of Silviculture and Forest Management at Guangxi University, Doctor's Degree in Forest Management, Beijing Forestry University. He is an expert in the management of Eucalyptus plantations and works on C and N cycling in different ecosystems. QD is a Professor of Ecology at South China Botanical Garden in Guangzhou, China, Doctor's Degree in Ecology at Chinese Academy of Sciences. He works on soil organic matter (both $\mathrm{C}$ and $\mathrm{N}$ ) and phosphorus dynamics in different ecosystems under global change.

\section{Funding}

This work was supported by the National Natural Science Foundation of China (No. 31460196 and 31870461), the Innovation Project of Guangxi Graduate Education (No. YCBZ2018012), the "Hundred Talent Program" of South China Botanical Garden at the Chinese Academy of Sciences (No. Y761031001), and the "Young Top-notch Talent" in Pearl River talent plan of Guangdong Province, and by the Science (No. 2019QN01L763).

\section{Availability of data and materials}

Not applicable. Journal style has been followed and dataset identifiers including DOls have been expressed as full URLS.

\section{Declarations}

Ethics approval and consent to participate Not applicable.

Consent for publication Not applicable. 


\section{Competing interests}

The authors declare that they have no known competing financial interests or personal relationships that could have appeared to influence the work reported in this paper.

\section{Author details}

${ }^{1}$ Key Laboratory of Vegetation Restoration and Management of Degraded Ecosystems, South China Botanical Garden, Chinese Academy of Sciences, Guangzhou 510650, China. ${ }^{2}$ Center for Plant Ecology, Core Botanical Gardens, Chinese Academy of Sciences, Guangzhou 510650, China. ${ }^{3}$ State Key Laboratory of Conservation and Utilization of Subtropical Agro-bioresources, College of Forestry, Guangxi University, Nanning 530004, China. ${ }^{4}$ Experimental Center of Topical Forestry, Chinese Academy of Forestry, Pingxiang 532600, China.

Received: 6 July 2021 Accepted: 19 August 2021

Published online: 14 September 2021

\section{References}

Arbuckle JL (2006) Amos (version 7.0) [computer program]. SPSS, Chicago

Baldrian P (2009) Microbial enzyme-catalyzed processes in soils and their analysis. Plant Soil Environ 55:370-378

Bini D, CAd S, Bouillet J-P, JLM G, EJBN C (2013a) Eucalyptus grandis and Acacia mangium in monoculture and intercropped plantations: evolution of soil and litter microbial and chemical attributes during early stages of plant development. Appl Soil Ecol 63:57-66. https://doi.org/10.1016/j.apsoil.2012.09. 012

Bini D, Fiqueiredo AF, da Silva MCP, RLdeF V, EJBN C (2013b) Microbial biomass and activity in litter during the initial development of pure and mixed plantations of Eucalyptus grandis and Acacia mangium. Rev Bras Ciência do Solo 37:76-85. https://doi.org/10.1590/S0100-06832013000100008

Bouillet JP, Laclau JP, Goncalves JLM, Moreira MZ, Trivelin PCO, Jourdan C, Silva EV, Piccolo MC, Tsai SM, Galiana A (2008) Mixed-species plantations of Acacia mangium and Eucalyptus grandis in Brazil: 2: $\mathrm{N}$ accumulation in the stands and $\mathrm{N}_{2}$ biological fixation. Forest Ecol Manag 255(12):3918-3930. https://doi. org/10.1016/j.foreco.2007.10.050

Bouillet J-P, Laclau J-P, Gonçalves JLM, Voigtlaender M, Gava JL, Leite FP, Hakamada R, Mareschal L, Mabiala A, Tardy F, Levillain J, Deleporte P, Epron D, Nouvellon Y (2013) Eucalypt and Acacia tree growth over entire rotation in single-and mixed-species plantations across five sites in Brazil and Congo. Forest Ecol Manag 301:89-101. https://doi.org/10.1016/jfforeco.2012.09.019

Bowles TM, Acosta-Martínez V, Calderón F, Jackson LE (2014) Soil enzyme activities, microbial communities, and carbon and nitrogen availability in organic agroecosystems across an intensively-managed agricultural landscape. Soil Biol Biochem 68:252-262. https://doi.org/10.1016/j.soilbio.2 013.10 .004

Epron D, Nouvellon Y, Mareschal L, Moreira RM, Koutika L-S, Geneste B, DelgadoRojas JS, Laclau J-P, Sola G, Gonçalves JLM, Bouillet J-P (2013) Partitioning of net primary production in Eucalyptus and Acacia stands and in mixed-species plantations: two case-studies in contrasting tropical environments. Forest Ecol Manag 301:102-111. https://doi.org/10.1016/j.foreco.2012.10.034

Firn J, Erskine PD, Lamb D (2007) Woody species diversity influences productivity and soil nutrient availability in tropical plantations. Oecologia 154:521-533. https://doi.org/10.1007/s00442-007-0850-8

Forrester DI, Bauhus J, Cowie AL (2005) On the success and failure of mixedspecies tree plantations: lessons learned from a model system of Eucalyptus globulus and Acacia mearnsii. Forest Ecol Manag 209:147-155. https://doi. org/10.1016/j.foreco.2005.01.012

Forrester DI, Bauhus J, Cowie AL, Vanclay JK (2006) Mixed-species plantations of Eucalyptus with N-fixing trees: a review. Forest Ecol Manag 233(2):211-230. https://doi.org/10.1016/j.foreco.2006.05.012

Garay I, Pellens R, Kindel A, Barros E, Franco AA (2004) Evaluation of soil conditions in fast-growing plantations of Eucalyptus grandis and Acacia mangium in Brazil: a contribution to the study of sustainable land use. Appl Soil Ecol 27:177-187. https://doi.org/10.1016/j.apsoil.2004.03.007

Goncalves JLM, Barros NF, Nambiar EKS, Novais RF (1997) Soil and stand management for short-rotation plantations. In: Nambiar EKS, Brown AG (eds) Management of soil, nutrients and water in tropical plantation forests. Australian Centre for International Agricultural Research, Canberra, pp 379418
Grace JB, Andersen TM, Smith MD, Seabloom E, Abdelman SJ, Meche G, Weiher E, Allain LK, Jutila H, Sankaran M, Knops J, Ritchie M, Willig MR (2007) Does species diversity limit productivity in natural grassland communities? Ecol Lett 10:680-689. https://doi.org/10.1111/j.1461-0248.2007.01058.x

Gruba P, Mulder J (2015) Tree species affect cation exchange capacity (CEC) and cation binding properties of organic matter in acid forest soils. Sci Total Environ 511:655-662. https://doi.org/10.1016/j.scitotenv.2015.01.013

Huang X, Liu S, You Y, Wen YG, Wang H, Wang JX (2017) Microbial community and associated enzymes activity influence soil carbon chemical composition in Eucalyptus urophylla plantation with mixing $\mathrm{N}_{2}$-fixing species in subtropical China. Plant Soil 414:199-212. https://doi.org/10.1007/s11104-016-3117-5

Huang XM, Liu SR, Wang H, Hu Z, Li ZG, You YM (2014) Changes of soil microbial biomass carbon and community composition through mixing $\mathrm{N}$-fixing species with Eucalyptus Urophylla in subtropical China. Soil Biol Biochem 73: 42-48. https://doi.org/10.1016/j.soilbio.2014.01.021

Jiang J, Wang YP, Tu M, Cao N, Yan J (2018) Soil organic matter is important for acid buffering and reducing aluminum leaching from acidic forest soils. Chem Geol 501:86-94. https://doi.org/10.1016/j.chemgeo.2018.10.009

Koutika L-S, Cafiero L, Bevivino A, Merino A (2020) Organic matter quality of forest floor as a driver of $C$ and $P$ dynamics in acacia and eucalypt plantations established on a Ferralic Arenosols, Congo. Forest Ecosyst 7:40. https://doi.org/10.1186/s40663-020-00249-w

Koutika L-S, Ngoyi S, Cafiero L, Bevivino A (2019) Soil organic matter quality along rotations in acacia and eucalypt plantations in the Congolese coastal plains. Forest Ecosyst 6:39. https://doi.org/10.1186/s40663-019-0197-8

Laclau J-P, Ranger J, Deleporte P, Nouvellon Y, Saint-André L, Marlet S, Bouillet J-P (2005) Nutrient cycling in a clonal stand of Eucalypt and an adjacent savanna ecosystem in Congo: 3. Input-output budgets and consequences for the sustainability of the plantations. Forest Ecol Manag 210:375-391

Lino IAN, Santos VM, Escobar IEC, Silva DKA, Araújo ASF, Maia LC (2016) Soil enzymatic activity in Eucalyptus grandis plantations of different ages. Land Degrad Develop 27:77-82. https://doi.org/10.1002/ldr.2454

Liu SR, Li XM, Niu LM (1998) The degradation of soil fertility in pure larch plantation in the northeastern part of China. Ecol Eng 10:75-86

May BM, Attiwill PM (2003) Nitrogen-fixation by Acacia dealbata and changes in soil properties 5 years after mechanical disturbance or slash-burning following timber harvest. Forest Ecol Manag 181:339-355. https://doi.org/10.1 016/50378-1127(03)00006-9

Nygren P, Leblanc HA (2015) Dinitrogen fixation by legume shade trees and direct transfer of fixed $\mathrm{N}$ to associated cacao in a tropical agroforestry system. Tree Physiol 35:134-137. https://doi.org/10.1093/ treephys/tpu116

Oliveira IR, Bordron B, Laclau J-P, Paula RR, Ferraz AV, Gonçalves JLM, Maire G, Bouillet JP (2021) Nutrient deficiency enhances the rate of short-term belowground transfer of nitrogen from Acacia mangium to Eucalyptus trees in mixed-species plantations. Forest Ecol Manag 491:119192. https://doi.org/1 0.1016/j.foreco.2021.119192

Paula RR, Bouillet J-P, Gonçalves JLM, Trivelin PCO, Balieiro FC, Nouvellon Y, Oliveira JC, Júnior JCD, Bordron B, Laclau J-P (2018) Nitrogen fixation rate of Acacia mangium wild at mid rotation in Brazil is higher in mixed plantations with Eucalyptus grandis hill ex maiden than in monocultures. Ann Forest Sci 75:14. https://doi.org/10.1007/s13595-018-0695-9

Paula RR, Bouillet J-P, Trivelin PCO, Zeller B, Gonçalves JLM, Nouvellon Y, Bouvet J-M, Plassard C, Laclau J-P (2015) Evidence of short-term belowground transfer of nitrogen from Acacia mangium to Eucalyptus grandis trees in a tropical planted forest. Soil Biol Biochem 91:99-108. https://doi.org/10.1016/j. soilbio.2015.08.017

Pereira APA, Durrer A, Gumiere T, Gonçalves José LM, Robin A, Bouillet JP, Wang J, Verma JP, Singh BK, Cardoso EJBN (2019) Mixed Eucalyptus plantations induce changes in microbial communities and increase biological functions in the soil and litter layers. Forest Ecol Manag 433:332-342. https://doi.org/1 0.1016/j.foreco.2018.11.018

Pereira APA, Zagatto MRG, Brandani CB, Mescolotti DL, Cotta SR, Gonçalves JLM, Cardoso EJBN (2018) Acacia changes microbial indicators and increases C and $\mathrm{N}$ in soil organic fractions in intercropped Eucalyptus plantations. Front Microbiol 9:1-13. https://doi.org/10.3389/fmicb.2018.00655

Pfautsch S, Rennenberg H, Bell TL, Adams MA (2009) Nitrogen uptake by Eucalyptus regnans and Acacia spp. - preferences, resource overlap and energetic costs. Tree Physiol 29:389-399. https://doi.org/10.1093/treephys/ tpn033 
Schimel J, Becerra CA, Blankinship J (2017) Estimating decay dynamics for enzyme activities in soils from different ecosystems. Soil Biol Biochem 114:511. https://doi.org/10.1016/j.soilbio.2017.06.023

Sicardi M, García-Pérchac F, Frioni L (2004) Soil microbial indicators sensitive to land use conversion from pastures to commercial Eucalyptus grandis (hill ex maiden) plantations in Uruguay. Appl Soil Ecol 27(2):125-133. https://doi. org/10.1016/j.apsoil.2004.05.004

Sinsabaugh RL, Lauber CL, Weintraub MN, Ahmed B, Allison SD, Crenshaw C, Contosta AR, Causack D, Frey S, Gallo ME, Gartner TB, Hobbie SE, Holland K, Keeler BL, Powers JS, Stursova M, Takacs-Vesbach C, Waldrop MP, Wallenstein MD, Zak DR, Zeglin LH (2008) Stoichiometry of soil enzyme activity at global scale. Ecol Lett 11:1252-1264. https://doi.org/10.1111/j.1461-0248.2008.01245.x

Tabatabai MA, Ekenler M, Senwo ZN (2010) Significance of enzyme activities in soil nitrogen mineralization. Commun Soil Sci Plan 41(5):595-605. https://doi. org/10.1080/00103620903531177

Tchichelle SV, Mareschal L, Koutika L-S, Epron D (2017) Biomass production, nitrogen accumulation and symbiotic nitrogen fixation in a mixed species plantation of eucalypt and Acacia on a nutrient-poor tropical soil. Forest Ecol Manag 403:103-111. https://doi.org/10.1016/j.foreco.2017.07.041

Vance ED, Brookes PC, Jenkinson DS (1987) An extraction method for measuring soil microbial biomass C. Soil Biol Biochem 19:703-707. https://doi.org/10.101 6/0038-0717(87)90052-6

Versini A, Laclau J-P, Mareschal L, Plassard C, Diamesso LA, Ranger J, Zeller B (2016) Nitrogen dynamics within and between decomposing leaves, bark and branches in Eucalyptus planted forests. Soil Biol Biochem 101:55-64. https://doi.org/10.1016/j.soilbio.2016.06.034

Voigtlaender M, Brandani CB, Caldeira DRM, Tardy F, Bouillet JP, Gonçalves JLM, Moreira MZ, Leite FP, Brunet D, Paula RR, Laclau J-P (2019) Nitrogen cycling in monospecific and mixed-species plantations of Acacia mangium and Eucalyptus at 4 sites in Brazil. Forest Ecol Manag 436:56-67. https://doi.org/1 0.1016/j.foreco.2018.12.055

Voigtlaender M, Laclau JP, Gonalves JLDM, Piccolo MDC, Moreira MZ, Nouvellon Y, Ranger J, Bouillet J-P (2012) Introducing Acacia mangium trees in Eucalyptus grandis plantations: consequences for soil organic matter stocks and nitrogen mineralization. Plant Soil 352:99-111. https://doi.org/10.1007/ s11104-011-0982-9

Wang H, Liu SR, Mo JM, Wang JX, Makeschin F, Wolff M (2010) Soil organic carbon stock and chemical composition in four plantations of indigenous tree species in subtropical China. Ecol Res 25:1071-1079. https://doi.org/10.1 007/s11284-010-0730-2

Yao XY, Li YF, Liao LN, Sun G, Wang HX, Ye SM (2019) Enhancement of nutrient absorption and interspecific nitrogen transfer in a Eucalyptus urophylla $X$ eucalyptus grandis and Dalbergia odorifera mixed plantation. Forest Ecol Manag 449:117465. https://doi.org/10.1016/j.foreco.2019.117465

Yao XY, Liao LN, Huang YZ, Fan G, Yang M, Ye SM (2021) The physiological and molecular mechanisms of $\mathrm{N}$ transfer in Eucalyptus and Dalbergia odorifera intercropping systems using root proteomics. BMC Plant Biol 21:201. https:// doi.org/10.1186/s12870-021-02969-9

You Y, Huang X, Zhu H, Liu S, Liang H, Wen Y, Wang H, Cai D, Ye D (2018) Positive interactions between Pinus massoniana and Castanopsis hystrix species in the uneven-aged mixed plantations can produce more ecosystem carbon in subtropical China. Forest Ecol Manag 410:193-200. https://doi. org/10.1016/j.foreco.2017.08.025

Zhao BC, Xu JD, Chen BY, Cao XF, Yuan TQ, Wang SF, Charlton A, Sun R-C (2018) Selective precipitation and characterization of lignin-carbohydrate complexes (LCCS) from Eucalyptus. Planta 247(5):1077-1087. https://doi.org/10.1007/ s00425-018-2842-9

\section{Submit your manuscript to a SpringerOpen ${ }^{\circ}$ journal and benefit from:}

- Convenient online submission

- Rigorous peer review

- Open access: articles freely available online

- High visibility within the field

- Retaining the copyright to your article

Submit your next manuscript at $\boldsymbol{\nabla}$ springeropen.com 